\title{
Long-Term Climate Change at Four Rural Stations in Minnesota, $1920-2010$
}

\author{
Fei Yuan ${ }^{1} \&$ Martin Mitchell ${ }^{1}$ \\ ${ }^{1}$ Professor, Department of Geography, Minnesota State University, Mankato, USA \\ Correspondence: Martin Mitchell, Professor, Morris Hall 206, Department of Geography, Minnesota State \\ University, Mankato, MN 56001, USA. Tel: 507-389-1610; Fax: 507-389-2980. E-mail: \\ martin.mitchell@mnsu.edu
}

$\begin{array}{lc}\text { Received: July 29, } 2014 & \text { Accepted: August 14, } 2014 \quad \text { Online Published: August 24, } 2014 \\ \text { doi:10.5539/jgg.v6n3p228 } & \text { URL: http://dx.doi.org/10.5539/jgg.v6n3p228 }\end{array}$

\begin{abstract}
Temperature data from 1920-2010 from four rural Minnesota stations were classified into three 30-year timeframes and examined for differences and trends in temperature (Tmax and Tmin), precipitation, and growing season variables: start of season (SOS), end of season (EOS) and length of season (LOS). These variables were subjected to an ANOVA, and Tukey test to ascertain statistical differences between the 30-year datasets. Subsequently, a Change Point analysis was applied pursuant to temperature and precipitation trends to determine the start and termination of temporal trends occurring within the dataset without the imposition of 30-year timeframes. The main findings were: (1) precipitation has increased significantly in May and June since 1985 and that the last 30-year timeframe possessed more precipitation (69-206 mm/2.7-8.1") than the first 30 years, (2) mean Tmin increased significantly at all four stations during the last 30 -year period relative to the middle period but not the initial period, (3) Tmax proved significantly warmer at only two stations during the initial 30-year period (1920-1949), (4) the length of growing season increased with an earlier onset or start being the chief variable at three of the four stations. Our Change Point analysis further highlights differences and trends superimposed over the 30-year bracketing of climate data. The regional role of water vapor as a greenhouse gas and landuse/cover factors, along with anthropogenic $\mathrm{CO}_{2}$ loading at a planetary scale, are argued to be partially causative, albeit specific weights were not assigned to each criterion as this task proved outside the scope of this study.
\end{abstract}

Keywords: climate change, Minnesota, temperature (Min and Max), precipitation, growing season, ANOVA, tukey test and change point analysis

\section{Introduction}

\subsection{Overall Climate Change: Context}

Climate change includes change either in average weather conditions or in the distribution of weather events relative to their average conditions over long periods of time. Oceanic circulation, solar radiation changes, biotic processes, volcanic eruptions, and human-induced alterations can all result in climate change. Since 1880, global temperatures rose until 1940, then decreased to 1980, and have since risen yielding a global temperatures increase of $0.8^{\circ} \mathrm{C}\left(1.5^{\circ} \mathrm{F}\right)$ (Miller et al. 2005). Although, anthropogenic $\mathrm{CO}_{2}$ emissions have resulted in $\mathrm{CO}_{2}$ concentrations of $390 \mathrm{ppm}$ versus a pre-Industrial level (circa 1850) of $280 \mathrm{ppm}$, assigning the exact weight to which anthropogenic $\mathrm{CO}_{2}$ emissions are responsible remains difficult given: (1) the commensurate scope of anthropogenic land use changes; and (2) the termination of prolonged sunspot minima cycles contributing to global cooling associated with the Little Ice Age (1275-1850) (Grove 1990).

\subsection{Regional and Local Scale Climate Change}

Climate change at the local and regional scale is a more recent concern. Examples include: (1) the more frequent incidence of heat waves and extremely high dew points $\left(>21^{\circ} \mathrm{C} / 70^{\circ} \mathrm{F}\right)$ in the Midwest (Changnon 2006); (2) an increase in growing season length throughout the core states of Midwest from 1911-2000 (Miller et al. 2005); (3) decreased precipitation and increased temperature associated with the urbanization and agricultural transformation of South Florida (Pielke 1999). Other regional climate change themes associated with a warmer atmosphere include longer periods of drought punctuated with more intense precipitation events (MnDNR 2008). 
The recent 2012 drought that covered $89 \%$ of the U.S. Corn belt at the peak of the growing season possessed the warmest March-August temperatures on record and the seventh driest March-August. This event has been followed an extremely wet 2014 in the upper Mississippi River basin, with Minneapolis receiving 82\% of its annual mean precipitation by June 20, 2014 (NOAA 2012 and MnDNR 2014)

Within Minnesota, continental polar masses originating from Canada, maritime tropical air masses from the Gulf of Mexico or highly modified air masses from the Pacific vie for dominance, which makes Minnesota ideal for examining climate change because one set of overriding controls is not well entrenched. Moreover, few long-term climate change studies examining Minnesota exist. Baker (1962) studied seasonal and annual temperature and precipitation trends at five Minnesota stations. He found a winter warming trend from 1900 to 1958. Ruschy et al. (1991) noted abrupt spring and autumnal changes in the daily temperature range, from low winter values to higher non-winter values in the Minneapolis-St. Paul temperature record, a feature that was even more evident in five rural and small town Minnesota Stations.

Baker et al. (1993) found an agriculturally favorable climatic period existed in the Corn Belt, including Minnesota, for approximately 18 years beginning in the mid-1950s and ending in 1974. Skaggs et al. (1995) used 13 years' running standard deviation in eastern Minnesota to conclude: (1) the recent interannual minimum temperature variability that ended in the 1970s was found to be a nearly consistent feature over the US, and (2) temperature variability was not constant in time with a minimum in interannual variability in 1960s, followed by increased variability from middle of 1970s to 1990s. Earlier, Skaggs and Baker (1985) concluded a general increase in length of growing season (LOS) occurred from 1899-1982 at five rural Minnesota stations, but their finding was tempered by substantial interannual variation.

Roy and Yuan (2009) examined the trend in extreme summer seasonal temperatures across the Minneapolis-St. Paul (Twin Cities) Metropolitan Area (TCMA) associated with urbanization from 1975 to 2002. Their results revealed a greater rate of increase in overall minimum temperatures, resulting in a slightly declining trend in diurnal temperature range for the stations in the TCMA. They also found negative trends in extreme maximum temperatures, accompanied by positive trends in extreme minimum temperatures.

\subsection{Importance of Climate Change in Minnesota}

This study complements these previous studies by specifically examining trends in temperature (including length of growing season) over a longer period and including precipitation, something the earlier studies omitted and underpins the state's non-irrigation oriented agricultural economy. Using four rural stations representing northwest, northeast, southwest and southeast Minnesota, our objectives include discerning changes across three 30-year periods in: (1) yearly and monthly maximum temperature (Tmax) and minimum temperature (Tmin), (2) precipitation from 1920 to 2010; and (3) differentiating any differences in the start, end, and length of the growing season over the 90 -year timespan using three 30 -year time frames, as well as comparing the 30 -year sets to the changes within the whole time series detected by the Change Point analysis.

\section{Study Site}

Located in the Upper Midwestern United States (US) with a total area of 225,000 $\mathrm{km}^{2}\left(87,000 \mathrm{mi}^{2}\right)$, Minnesota's climate is heavily influenced by its geographical location where continental polar $(\mathrm{cP})$, maritime tropical $(\mathrm{mT})$ and modified maritime polar (mP) regularly collide (Seeley 2006; Hart and Ziegler 2008). Monthly mean average temperatures in Minnesota range from $-15^{\circ} \mathrm{C}\left(5^{\circ} \mathrm{F}\right)$ at International Falls to $23.2^{\circ} \mathrm{C}\left(73.8^{\circ} \mathrm{F}\right)$ in Minneapolis. Annual precipitation ranges from more than $937 \mathrm{~mm}\left(36.9^{\prime \prime}\right)$ in the southeast corner to less than $544 \mathrm{~mm}$ (21.4") in the upper northwest of the Red River valley (NCDC 2013). Annual evapotranspiration rates trend downwards from southwest to northeast with the annual water balance ranging from $254 \mathrm{~mm}\left(+10^{\prime \prime}\right)$ in the extreme northeast to $-254 \mathrm{~mm}(-10 ")$ along the western border with North Dakota (NCDC 2006 and MnDNR 1990). Missed by the Pleistocene glaciations, the southeastern section of the state along the Mississippi River is comprised of hilly terrain with forested uplands and intervening agricultural valleys. The south central and southwestern regions possess rich soils borne of glacial deposition. Scoured multiple times, northeast Minnesota is covered mostly by forest with bedrock exposed in numerous locales, whereas, northwestern Minnesota consists of the former bottom of glacial Lake Agassiz and is vegetated by natural prairies (many of which have been drained to facilitate sugar beet production), wet peatlands, and aspen parklands.

\section{Data and Methods}

\subsection{Data Acquisition, Station Selection, and Processing}

Daily station-level climate data were obtained from Daily Global Historical Climatology Network (GHCN-Daily) Version 3.0 dataset, maintained at the National Oceanic and Atmospheric Administration's (NOAA) National 
Climatic Data Center (NCDC). Its processing system produces the official archive for U.S. daily data (Menne et al. 2012). These data originate from a variety of sources ranging from paper forms completed by volunteer observers to synoptic reports from automated weather stations. To ensure high-quality historical and real-time daily data, a comprehensive set of fully automated quality assurance procedures have been applied operationally in the GHCN-Daily quality assurance system (Durre et al. 2010). An overview of the GHCN-Daily database and additional details about the quality control techniques used to maintain the accuracy of the GHCN dataset can be found in Menne et al. (2012) and Durre et al. (2010).

We selected four rural Minnesota stations because of continuous climate records extending from 1920 through 2010 with minimal missing data. The four stations: (1) Crookston, (2) Grand Rapids, (3) Morris and (4) Waseca are located in northwest, northeast, west central and southeast Minnesota, respectively (Figure 1). We excluded Twin Cities Metropolitan Area stations because of the dominance of urban land cover and urban heat island effects. From the GHCN database, daily maximum and minimum temperatures, and precipitations for the four stations from 1920 to 2010 were extracted using a customized VB.NET program. The extracted daily data were then imported into Microsoft Access 2010 to calculate monthly and annual temperatures and precipitation. In addition, based on the daily minimum temperature data, the three growing season indices: (1) start of growing season (SOS), (2) end of growing season (EOS), and (3) length of growing season (LOS) were calculated using Microsoft Access' SQL based on the U.S. Department of Agriculture (USDA) definition of the growing season as the length between the last and first freezes $\left(0^{\circ} \mathrm{C} / 32^{\circ} \mathrm{F}\right)$ (USDA 1999).

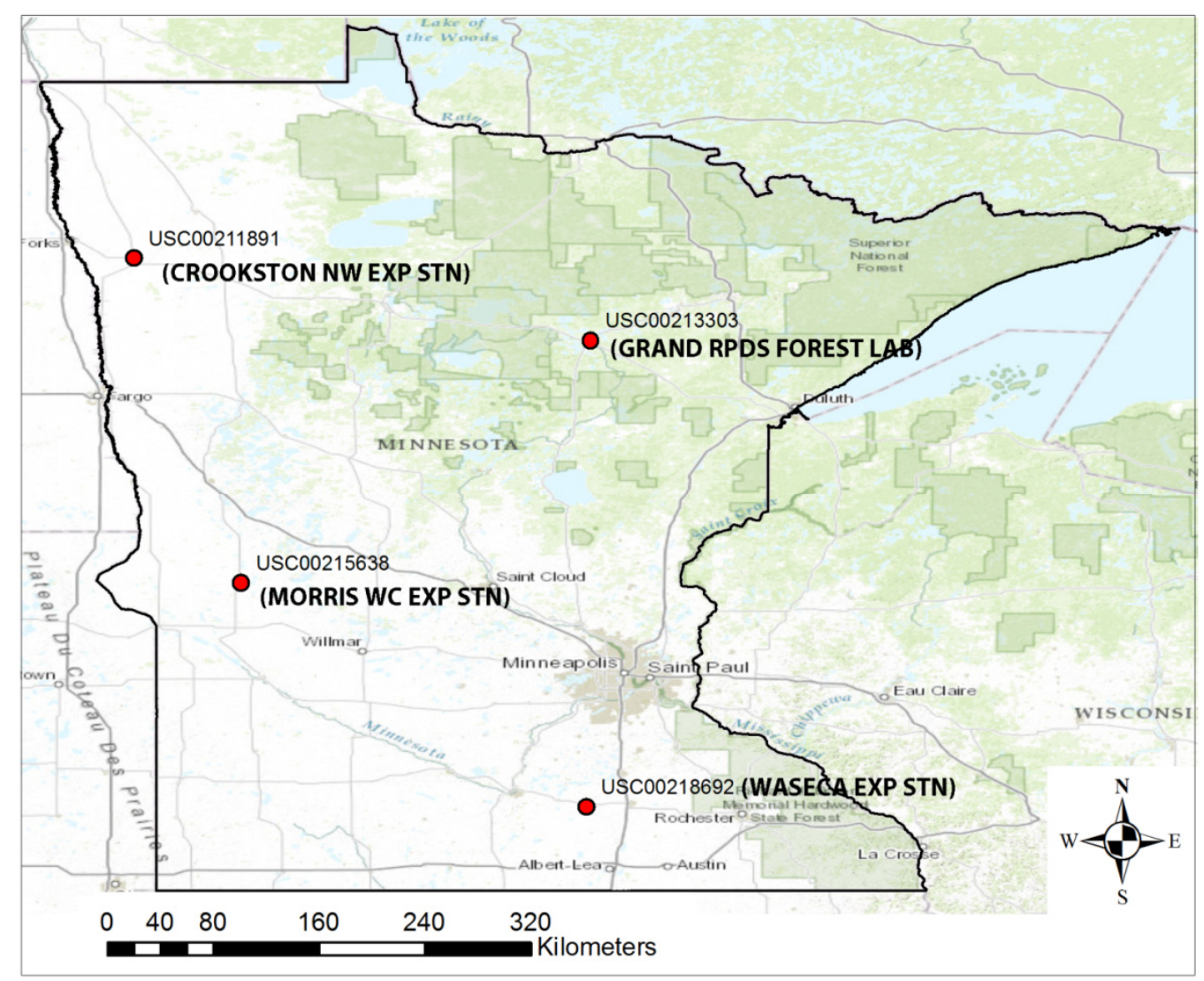

Figure 1. Locations of the four weather stations in Minnesota

\subsection{Statistical Methods and Justifications}

The extracted daily weather data were divided into three 30-year normal sets (the last set contained 31 years) pursuant to the World Meteorological Association's (WMO) definition of normal (WMO 1982). The 30-year sets were assessed for normality by means of the quantile-quantile (Q-Q) plot, which showed a linear distribution of the data. Subsequently, a formal test of normality was conducted using the Shapiro-Wilkes Test where the p-values ( $>0.77)$ confirmed normality. Consequently, we used parametric statistics.

The ANOVA test determined if differentiation existed and confirmed whether the assumptions of independence, 
normal distribution and constant variance existed. If the ANOVA yielded differentiation, a Tukey test was applied to ascertain which pairs of 30-year sets were different. Finally, we ran a Change Point analysis across the full 91 years of data to isolate distinct temporal breaks between blocks of data without aggregating or forcing them into 30-year normal timeframes. Change Point analysis is a tool for determing whether a change has taken place. To detect multiple changes within our time series, an R package called "changepoint" was used. Detailed information about the method and algorithm implemented in this package can be found in Killick and Eckley (2013). Subsequently, the Change Point results were compared to the 30 -year sets.

\section{Results}

\subsection{Monthly Temperature and Precipitation Values and Trends}

The 30-year averages for temperature and precipitation are depicted in Table 1. Summarized in Figure 2, the average Tmax of the four stations ranged from $-7.6^{\circ} \mathrm{C}\left(18.2^{\circ} \mathrm{F}\right)$ in January to $27^{\circ} \mathrm{C}\left(80.6^{\circ} \mathrm{F}\right)$ in July. Pursuant to Tmax, Crookston (northwest) had the lowest January reading at $-9.8^{\circ} \mathrm{C}$ compared to Waseca's $-5.5^{\circ} \mathrm{C}$ in the southeast, resulting in a spread of $4.3^{\circ} \mathrm{C}$. In July, Waseca had the highest temperature at $28.5^{\circ} \mathrm{C}$ and Grand Rapids in the northeast with $25.6^{\circ} \mathrm{C}$ recorded the coolest, yielding a $3.1^{\circ} \mathrm{C}$ difference. The combined total average for Tmin in January was $-18.8^{\circ} \mathrm{C}$ and for July $14.5^{\circ} \mathrm{C}$. Individually, Crookston again recorded the lowest mean monthly minimum in January at $-20.6^{\circ} \mathrm{C}$ with Waseca's $-16.1^{\circ} \mathrm{C}$ being the highest, yielding a $4.5^{\circ} \mathrm{C}$ difference. For summer, Waseca's $15.9^{\circ} \mathrm{C}$ was the warmest Tmin while Grand Rapids (northeast) had the lowest at $12.6^{\circ} \mathrm{C}$, resulting in a $3.3^{\circ} \mathrm{C}$ difference.

The ANOVA results for mean annual Tmax found the 30-year normals for Morris and Waseca were significantly different (Table 2). The Tukey test further revealed that both 1950-1979 and 1980-2010 were different, i.e. cooler relative to $1920-1949$ by $1-2^{\circ} \mathrm{C}$ at Morris and Waseca (Table 3). When the 91-year data set was subjected to the Change Point analysis Waseca's warmest mean annual Tmax occurred from 1920 through 1965, which was followed by a distinct cooling through 1985 and another warmer, but cooler set of years relative to 1920-1965, from 1985-2010. Results from Morris were similar, although the 1965-2010 period showed more variability than at Waseca (Figure 3a).

Table 1. 30-yr mean of Tmax, Tmin, and precipitation for the four stations $\left({ }^{\circ} \mathrm{C} / \mathrm{mm}\right)$

\begin{tabular}{cccccccccc}
\hline & \multicolumn{3}{c}{$1920-1949$} & \multicolumn{3}{c}{$1950-1979$} & \multicolumn{3}{c}{$1980-2010$} \\
\hline Station Names & Tmax & Tmin & PRCP & Tmax & Tmin & PRCP & Tmax & Tmin & PRCP \\
Crookston & 10.70 & -1.49 & 496.52 & 10.71 & -1.88 & 517.39 & 10.49 & -1.16 & 565.64 \\
Grand Rapids & 10.81 & -2.72 & 612.37 & 10.52 & -2.32 & 676.04 & 11.08 & -1.45 & 728.14 \\
Morris & 12.72 & -0.06 & 574.20 & 10.99 & -0.60 & 601.80 & 11.53 & 0.10 & 666.04 \\
Waseca & 13.67 & 1.60 & 692.90 & 12.36 & 0.57 & 769.28 & 12.69 & 1.63 & 899.36 \\
\hline
\end{tabular}

Table 2. ANOVA-test results for mean Tmax, Tmin, and precipitation of the three 30-yr periods

\begin{tabular}{cccc}
\hline Station Names & $\begin{array}{c}\text { P-value for three } 30-\mathrm{yr} \\
\text { mean Tmax }\end{array}$ & $\begin{array}{c}\text { P-value for three } 30 \text {-yr mean } \\
\text { Tmin }\end{array}$ & $\begin{array}{c}\text { P-value for three } 30 \text {-yr mean } \\
\text { PRCP }\end{array}$ \\
\hline Crookston & 0.69 & $\mathbf{0 . 0 2 8}^{*}$ & $\mathbf{0 . 0 3 9 *}$ \\
Grand Rapids & 0.097 & $\mathbf{0 . 0 0 0 * * *}$ & $\mathbf{0 . 0 0 0 * * *}$ \\
Morris & $\mathbf{0 . 0 0 0 * * *}$ & $\mathbf{0 . 0 2 3}^{*}$ & $\mathbf{0 . 0 1 4 *}$ \\
Waseca & $\mathbf{0 . 0 0 0 * * *}$ & $\mathbf{0 . 0 0 0}^{* * *}$ & $\mathbf{0 . 0 0 0 * * *}$ \\
\hline
\end{tabular}

$*, * *$ and $* * *$ Significant at the levels of $5 \%, 1 \%$ and $0.1 \%$, respectively. 
Table 3. Tukey-test results for mean Tmax, Tmin, and precipitation pairs of the three 30-yr periods (1: from 1920-1949; 2: from 1950-1979; 3: from 1980-2010)

\begin{tabular}{cccccccc}
\hline & \multicolumn{3}{c}{ Tmax } & \multicolumn{2}{c}{ Tmin } & \multicolumn{2}{c}{ PRCP } \\
\hline Station & Period Pairs & Diff $\left({ }^{\circ} \mathrm{C}\right)$ & P-value & Diff $\left({ }^{\circ} \mathrm{C}\right)$ & P-value & Diff $(\mathrm{mm})$ & P-value \\
Names & & & & & & & \\
& $2-1$ & - & - & -0.39 & 0.299 & 20.87 & 0.731 \\
Crookston & $3-1$ & - & - & 0.33 & 0.425 & $\mathbf{6 9 . 1 2}$ & $\mathbf{0 . 0 3 5 *}$ \\
& $3-2$ & - & - & $\mathbf{0 . 7 3}$ & $\mathbf{0 . 0 2 1}^{*}$ & 48.25 & 0.189 \\
Grand & $2-1$ & - & - & 0.40 & 0.271 & 63.67 & 0.066 \\
Rapids & $3-1$ & - & - & $\mathbf{1 . 2 7}$ & $\mathbf{0 . 0 0 0}^{* * *}$ & $\mathbf{1 1 5 . 7 7}$ & $\mathbf{0 . 0 0 0 * * *}$ \\
& $3-2$ & - & - & $\mathbf{0 . 8 7}$ & $\mathbf{0 . 0 0 3}^{* *}$ & 52.10 & 0.154 \\
Morris & $2-1$ & $\mathbf{- 1 . 7 3}$ & $\mathbf{0 . 0 0 0} * * *$ & -0.54 & 0.103 & 27.60 & 0.663 \\
& $3-1$ & $\mathbf{- 1 . 1 9}$ & $\mathbf{0 . 0 0 0} * * *$ & 0.16 & 0.820 & $\mathbf{9 1 . 8 3}$ & $\mathbf{0 . 0 1 2 *}$ \\
& $3-2$ & 0.54 & 0.166 & $\mathbf{0 . 7 0}$ & $\mathbf{0 . 0 2 3 *}$ & 64.24 & 0.110 \\
Waseca & $2-1$ & $\mathbf{- 1 . 3 1}$ & $\mathbf{0 . 0 0 0 * * *}$ & $\mathbf{- 1 . 0 3}$ & $\mathbf{0 . 0 0 0} * * *$ & 76.38 & 0.143 \\
& $3-1$ & $\mathbf{- 0 . 9 8}$ & $\mathbf{0 . 0 0 3} * *$ & 0.03 & 0.993 & $\mathbf{2 0 6 . 4 5}$ & $\mathbf{0 . 0 0 0 * * *}$ \\
& $3-2$ & 0.33 & 0.485 & $\mathbf{1 . 0 6}$ & $\mathbf{0 . 0 0 0 * * *}$ & $\mathbf{1 3 0 . 0 7}$ & $\mathbf{0 . 0 0 4 * *}$ \\
\hline
\end{tabular}

$*, * *$ and $* * *$ Significant at the levels of $5 \%, 1 \%$ and $0.1 \%$, respectively.
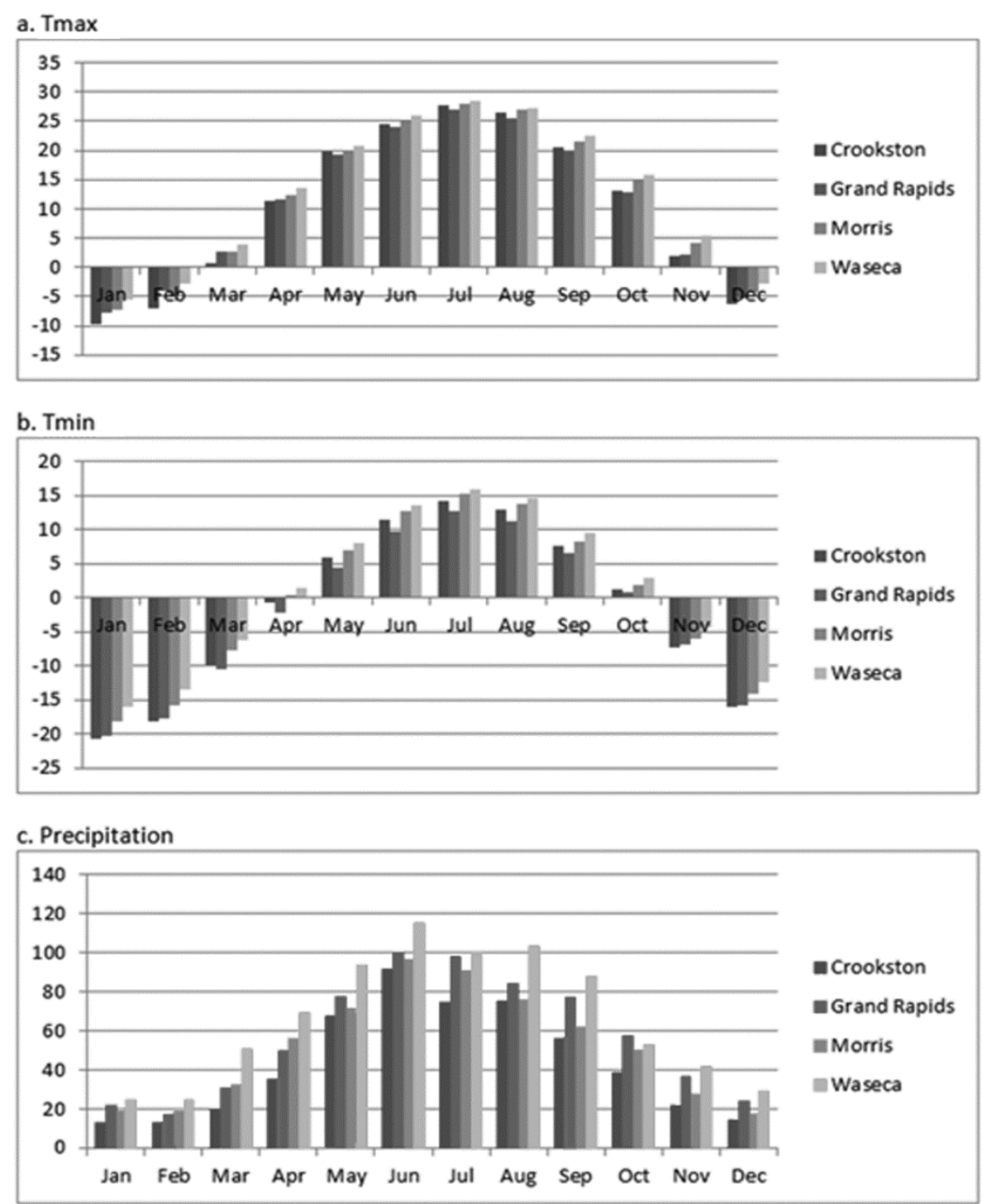

Figure 2. Mean Monthly $\operatorname{Tmax}\left({ }^{\circ} \mathrm{C}\right)$, Tmin $\left({ }^{\circ} \mathrm{C}\right)$, and Precipitation $(\mathrm{mm})$ Over the 90 Years at the Four Weather Stations 
Pursuant to mean annual Tmin, the ANOVA found all four stations were different (Table 2). According to the Tukey test $1980-2010$ was $0.7-1.06^{\circ} \mathrm{C}$ warmer than $1950-1979$ at all four stations, but not $1920-1949$ except for Grand Rapids (Table 3). At Grand Rapids 1980-2010 proved statistically warmer than both 1920-1949 and 1950-1980 while at Waseca 1980-2010 was warmer than 1950-1979 but not 1920-1949. Moreover, 1950-1979 also tested significantly cooler than 1920-1949 at Waseca. The Change Point analysis found a distinct warming at Crookston beginning in the middle 1990's, whereas, Grand Rapids from 1950 through 1995 experienced warming followed by yet another more pronounced warming period until 2010 (Figure 3b). At Morris and Waseca, a roughly 21-year cooling period from 1964 through 1985 was followed by the warmest block of years through 2010 (Figure 3).

\section{a. Change Point Analysis for Annual Tmax}
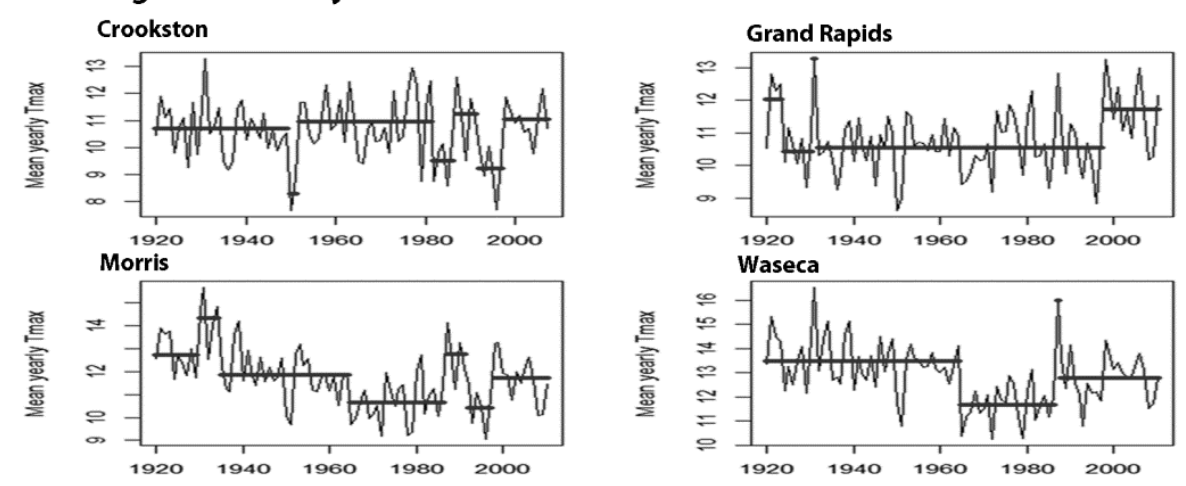

\section{b. Change Point Analysis for Annual Tmin}
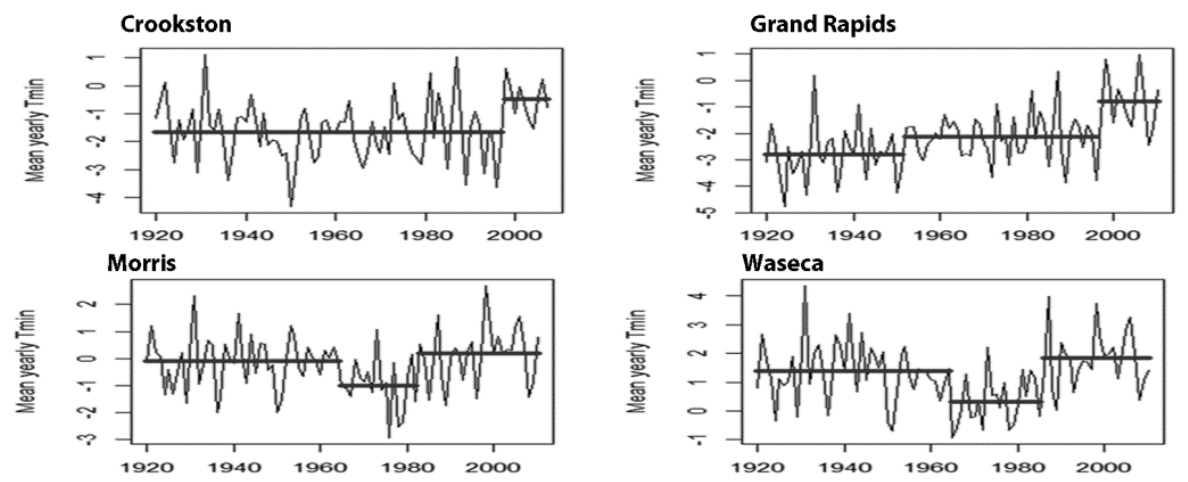

\section{c. Change Point Analysis for Annual Precipitation}
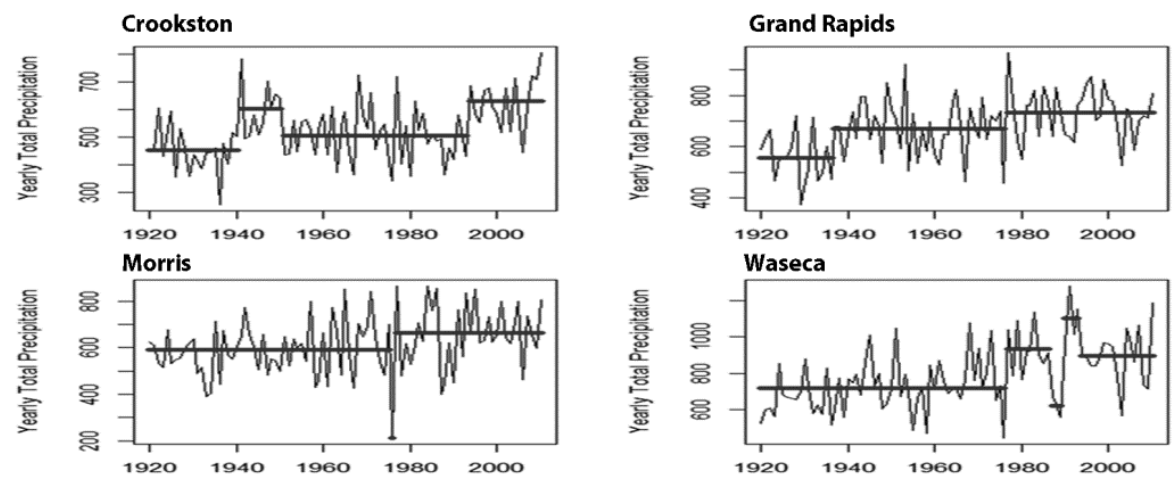

Figure 3. Change point analysis for annual Tmax, Tmin, and precipitation $\left({ }^{\circ} \mathrm{C} / \mathrm{mm}\right)$ 
When using Change Point analysis to examine the monthly Tmax and Tmin data for the growing season (defined as May through October rather than by the USDA frost-free definition), the following findings occurred (Figure 4). First, Tmax showed a decline from 1965 to 2010 at Waseca for August. In addition, October Tmax decline at three stations occurred since 1965 while at Crookston it began in the late 1970s. Regarding the other stations, nothing distinct was apparent. When examining Tmin, warmer springs and early summers, most notably May and June, were found at all four stations (Figure 5). In addition, Grand Rapids also had a warmer July starting in 1983. Warming at the northern stations (Crookston and Grand Rapids) commenced in 1970 in May and 1983 for June. At the southern stations (Morris and Waseca) both the May and June warming commenced in 1983 and lasted through 2010 (Figure 6).

Crookston

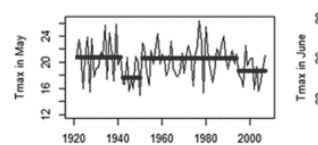

$1920 \quad 1940 \quad 1960 \quad 1980 \quad 2000$
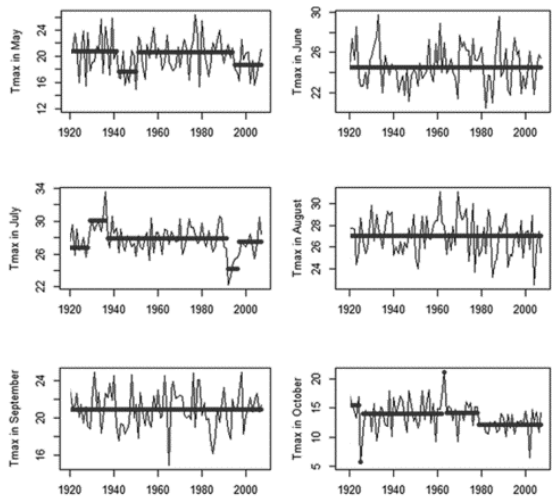

Morris
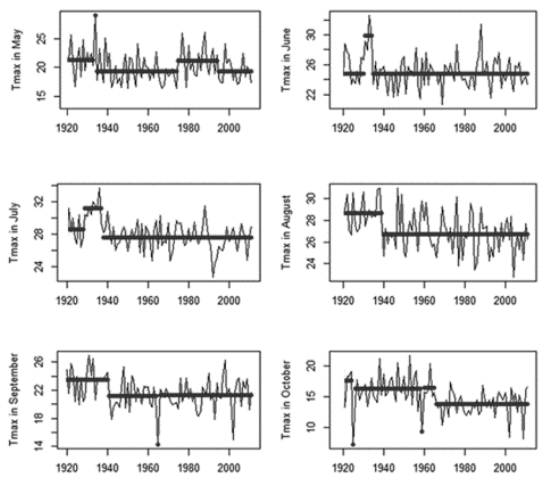
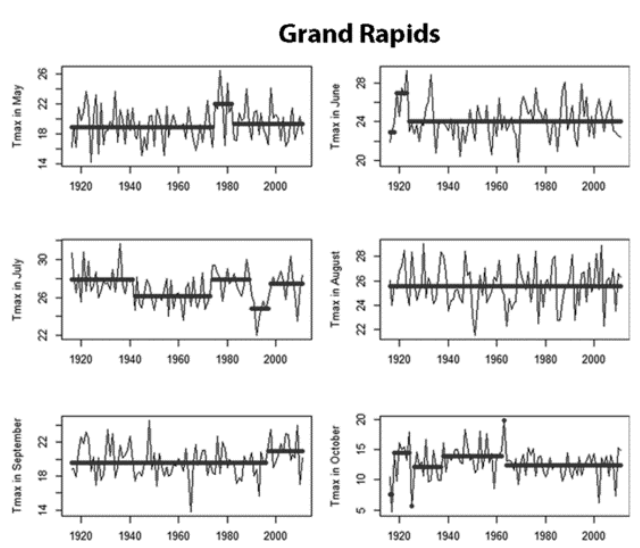

Waseca
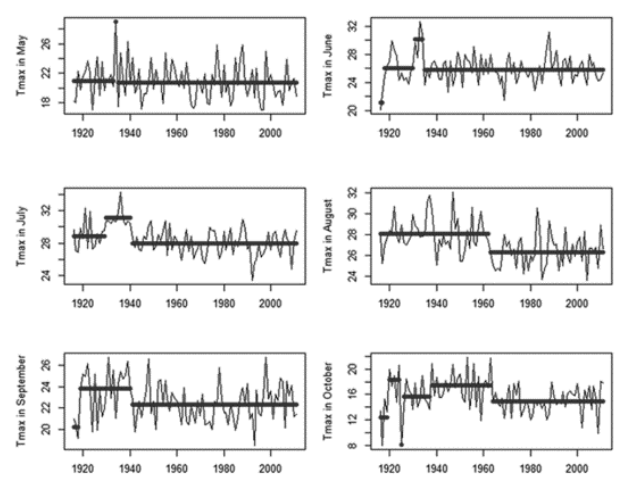

Figure 4. Change point analysis for growing season monthly $\operatorname{Tmax}\left({ }^{\circ} \mathrm{C}\right)$ 


\section{Crookston}

$=\underset{1900}{19500_{1960}^{1900}}$

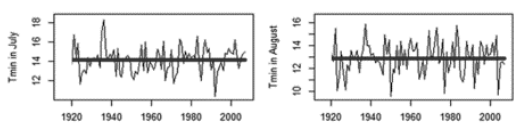

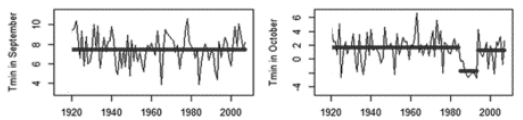

\section{Morris}

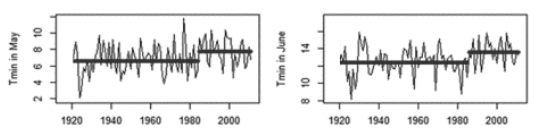

$=\underbrace{}_{1920}$

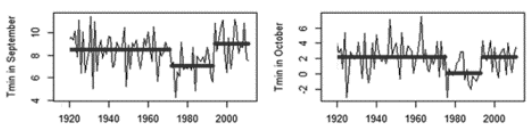

\section{Grand Rapids}

管:

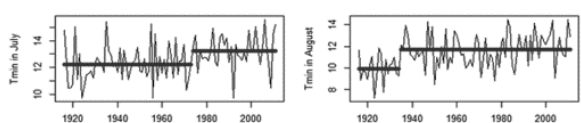

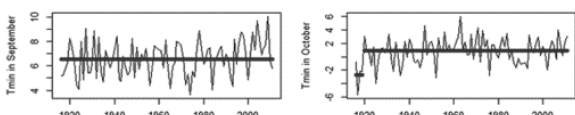

Waseca

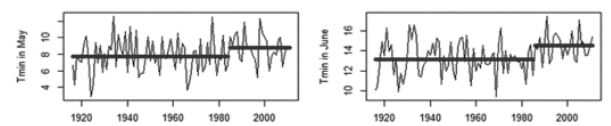

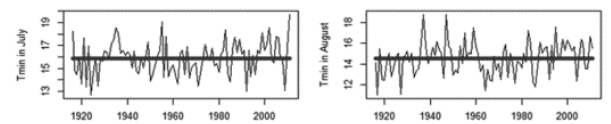

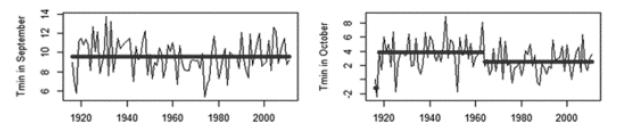

Figure 5. Change point analysis for growing season monthly $\operatorname{Tmin}\left({ }^{\circ} \mathrm{C}\right)$

Crookston

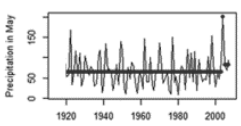

8.

等

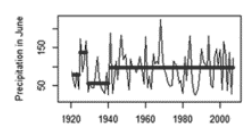

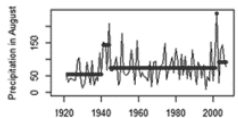

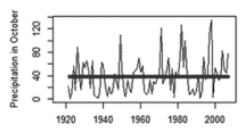

Morris

8.

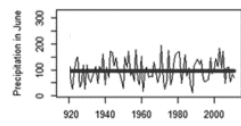

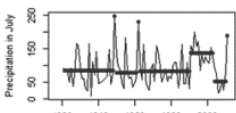

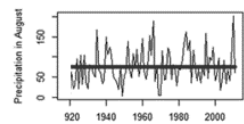

管

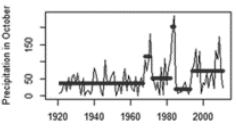

Grand Rapids

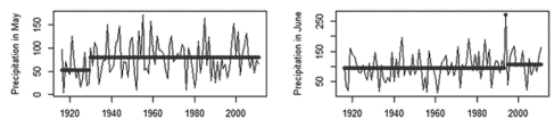

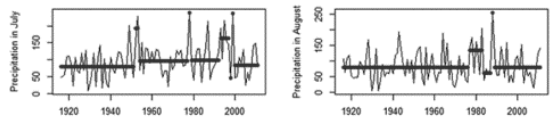

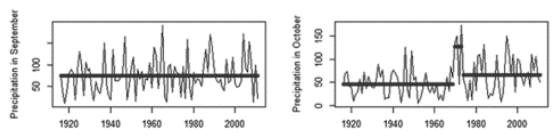

Waseca

等

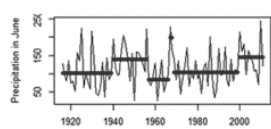

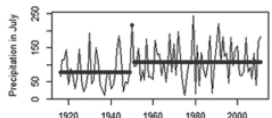

管

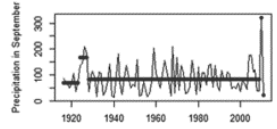

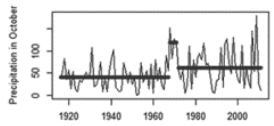

Figure 6. Change point analysis for growing season monthly Precipitation (mm) 

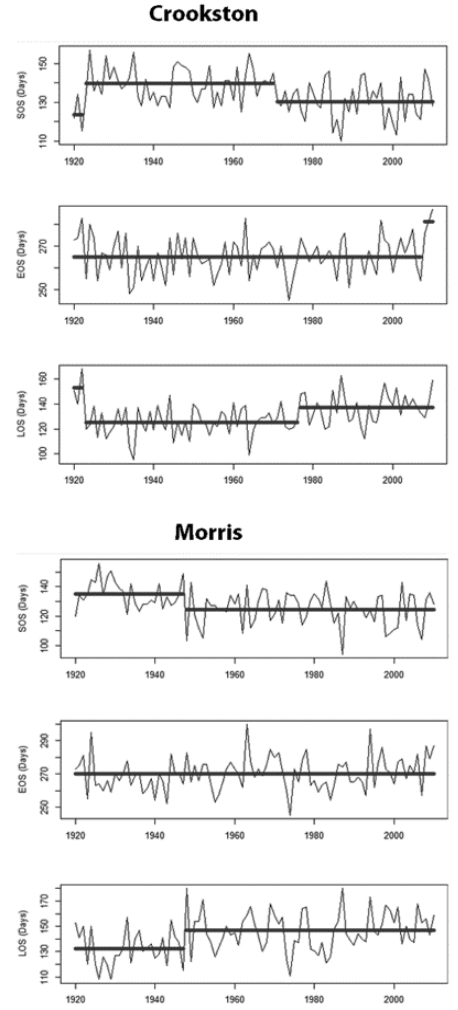
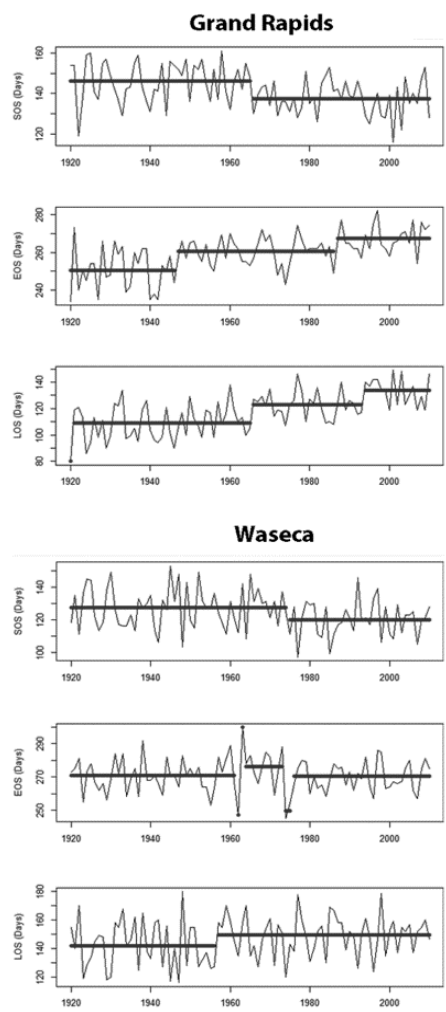

Figure 7. Change point analysis for growing season variables (SOS, EOS, LOS)

\subsection{Precipitation Values and Trends}

Qualitatively, each 30-year block at all four stations possessed more precipitation than the previous (Table 1). Precipitation data tested different with ANOVA at all four stations (Table 2). The Tukey test further found 1980-2010 possessed significantly more precipitation by $69-206 \mathrm{~mm}$ than 1920-1949 at four stations, especially for Grand Rapids and Waseca with P values less than 0.0001. Moreover, Waseca had significantly more precipitation from 1980-2010 to 1950-1979 (Table 3). The Change Point analysis of mean annual precipitation found the southern stations, Waseca and Morris experienced a wetter period commencing in the late 1970s and persisting through 2010. Grand Rapids also exhibited its wettest period beginning in 1978, however this was preceded by another weaker increase from 1940 through 1977. Crookston exhibited more variability prior to 1985, however, the post 1985 period again proved the wettest period (Figure 3c).

When examined on a growing season monthly basis, the Change Point analysis found Waseca and Morris had its wettest May and June from 1985-2010, while at the two northern stations, a wetter May and June were found from 1970-2010 and 1985-2010, respectively (Figure 6). From 1993-2010, September was wetter at Morris, but it also exhibited pronounced interannual variability.

\subsection{Length of Growing Season Values and Trends}

The start of the growing season, its termination and overall length as defined by the official USDA (1999) standard exhibited the following results (Table 4). First the start and length of the growing season (SOS and LOS) were found by the ANOVA to be different at all stations except Waseca (Table 5). Waseca did exhibit similar qualitative trends. The end of growing season (EOS) was only found to differ at Grand Rapids. The SOS from 1980-2010 differed significantly from 1920-1949 at all three stations (Table 6). At Morris, the SOS from 1950-1979 also differed significantly from 1920-1949. Regarding the LOS, the Turkey test again found 1980-2010 differed significantly from 1920-1949 at all three stations and from 1950-1979 at Crookston and Grand Rapids (Table 6). Although the 1980-2010 LOS was found to not differ from 1950-1979 at Morris, the 1950-1979 period differed significantly relative to 1920-1949. Finally, at Grand Rapids the EOS from 1920-1949 differed significantly from both 1950-1979 and 1980-2010. In particular, Grand Rapid showed the most distinctive 22 longer LOS, caused by 8-day earlier start and 14-day later end of the season. 
Table 4. 30-yr mean of SOS, EOS, and LOS (Day of Year)

\begin{tabular}{cccccccccc}
\hline & \multicolumn{3}{c}{$1920-1949$} & \multicolumn{3}{c}{$1950-1979$} & \multicolumn{3}{c}{$1980-2010$} \\
\hline Station Names & SOS & EOS & LOS & SOS & EOS & LOS & SOS & EOS & LOS \\
Crookston & 138.87 & 265.03 & 126.17 & 136.13 & 264.40 & 128.27 & 130.26 & 267.36 & 137.10 \\
Grand Rapids & 145.83 & 251.60 & 105.77 & 142.10 & 260.43 & 118.33 & 137.58 & 265.74 & 128.16 \\
Morris & 134.37 & 268.03 & 133.67 & 125.27 & 271.33 & 146.07 & 123.84 & 271.19 & 147.36 \\
Waseca & 127.33 & 270.67 & 143.33 & 125.67 & 272.23 & 146.57 & 120.19 & 269.68 & 149.48 \\
\hline
\end{tabular}

Table 5. ANOVA-test results for mean SOS, EOS, and LOS of the three 30-yr periods

\begin{tabular}{cccc}
\hline Station Names & $\begin{array}{c}\text { P-value for three } 30-\mathrm{yr} \\
\text { mean SOS }\end{array}$ & $\begin{array}{c}\text { P-value for three } 30 \text {-yr mean } \\
\text { EOS }\end{array}$ & $\begin{array}{c}\text { P-value for three } 30 \text {-yr mean } \\
\text { LOS }\end{array}$ \\
\hline Crookston & $\mathbf{0 . 0 0 3 * *}$ & 0.387 & $\mathbf{0 . 0 0 2 * *}$ \\
& $\mathbf{0 . 0 0 5 * *}$ & $\mathbf{0 . 0 0 0 * * *}$ & $\mathbf{0 . 0 0 0 * * *}$ \\
Grand Rapids & $\mathbf{0 . 0 0 0 * * *}$ & 0.361 & $\mathbf{0 . 0 0 1 * *}$ \\
Morris & 0.056 & 0.614 & 0.298 \\
Waseca & & & \\
\hline
\end{tabular}

$*, * *$ and $* * *$ Significant at the levels of $5 \%, 1 \%$ and $0.1 \%$, respectively.

Table 6. Tukey-test results for mean SOS, EOS, and LOS pairs of the three 30-yr periods

\begin{tabular}{|c|c|c|c|c|c|c|c|}
\hline \multirow[b]{2}{*}{$\begin{array}{l}\text { Station } \\
\text { Names }\end{array}$} & \multirow[b]{2}{*}{ Period Pairs } & \multicolumn{2}{|c|}{ SOS } & \multicolumn{2}{|c|}{ EOS } & \multicolumn{2}{|c|}{ LOS } \\
\hline & & $\begin{array}{c}\text { Diff } \\
\text { (Days) }\end{array}$ & P-value & $\begin{array}{c}\text { Diff } \\
\text { (Days) }\end{array}$ & P-value & Diff (Days) & P-value \\
\hline & $2-1$ & -2.73 & 0.522 & - & - & 2.10 & 0.797 \\
\hline \multirow[t]{2}{*}{ Crookston } & $3-1$ & -8.61 & $0.002 * *$ & - & - & 10.93 & $0.003^{* *}$ \\
\hline & $3-2$ & -5.88 & 0.052 & - & - & 8.83 & $0.021 *$ \\
\hline \multirow{4}{*}{$\begin{array}{l}\text { Grand } \\
\text { Rapids }\end{array}$} & $2-1$ & -3.73 & 0.298 & 8.83 & $0.000 * * *$ & 12.57 & $0.000 * * *$ \\
\hline & $3-1$ & -8.25 & $0.004 * *$ & 14.14 & $0.000 * * *$ & 22.39 & $0.000 * * *$ \\
\hline & $3-2$ & -4.52 & 0.167 & 5.31 & 0.052 & 9.83 & $0.007 * *$ \\
\hline & $2-1$ & -9.10 & $0.005^{* *}$ & - & - & 12.40 & $0.005^{* *}$ \\
\hline \multirow[t]{3}{*}{ Morris } & $3-1$ & -10.53 & $0.001 * *$ & - & - & 13.69 & $0.002 * *$ \\
\hline & $3-2$ & -1.43 & 0.865 & - & - & 1.29 & 0.940 \\
\hline & $2-1$ & - & - & - & - & - & - \\
\hline \multirow[t]{2}{*}{ Waseca } & $3-1$ & - & - & - & - & - & - \\
\hline & $3-2$ & - & - & - & - & - & - \\
\hline
\end{tabular}

*,** and $* * *$ Significant at the levels of $5 \%, 1 \%$ and $0.1 \%$, respectively.

When the growing season criteria are examined relative to Change Point analysis the longer growing season commences in 1978 at Crookston and 1965 at Grand Rapids with the latter exhibiting another increase in LOS commencing in 1985 (Figure 7). The southern stations experienced increases starting in 1950 at Morris and 1958 at Waseca. When examining the SOS and EOS certain temporal blocks again appear. First, the SOS changes at Morris and Grand Rapids in 1950 and 1975, respectively coincide with the LOS changes. At Crookston, the 1970 change in SOS was offset by EOS variability and thus did not appear causative per LOS until the late 1970s. At Waseca, the 1958 increase in LOS was initially driven by a short positive SOS variability and then shifted to EOS as primary factor from the early 1960's through the middle 1970s. Subsequently, an earlier SOS in 1975 at Waseca becomes the primary driver for the longer LOS through 2010 (thus reflecting the other three stations). Finally, EOS at Grand Rapids experienced two shifts: 1950-1985 and 1985-2010, both of which reinforced the LOS from 1965-2010, albeit from 1950-1964 the EOS was offset by SOS variability. 


\section{Discussion}

\subsection{Length of Growing Season Values and Trends}

The importance of the results needs to be discussed in the context of two points with the first taking the form of statement and the second as a question. First, post-Little Ice Age warming in the Northern Hemisphere exhibited warming from 1850 through the 1940s, which was followed by a 30-year cooling and then another warming trend beginning in the 1980s and continuing to the present. Second, how do our results "fit" into climate change drivers operating at a planetary versus regional scale? Our temperature findings generally follow the Northern Hemisphere trends stated above. The warm and dry 1930s and the warm 1940s exert influence on the 91-year data set and the 1950-1980 general Northern Hemisphere cooling was also apparent. This situation was most noticeable with Tmax.

The significant increase of Tmin at all four stations from 1980-2010 implies less nocturnal cooling, which was most notable in May and June, i.e spring and early summer. Some of this "significance" can be explained by the cessation of the 1950-80 general cooling. However, upon further examination, the primary question becomes, "What can explain less nocturnal cooling, especially when daytime Tmax from 1980-2010 did not test significantly warmer than the earlier eras? We argue that greenhouse gases combined with seasonal landuse practices are probable explanations though assigning exact weights to each is admittedly difficult and beyond the scope of this research.

As noted, atmospheric carbon dioxide concentrations have increased from $280 \mathrm{ppm}$ circa 1850 to the present level of $390 \mathrm{ppm}$. Although our temperature patterns fit this trend, we do not believe $\mathrm{CO}_{2}$ tells the whole story. Our precipitation findings unequivocally point to wetter conditions at all four stations from the 1980 or 1990s; a finding that parallels a 20-50\% increase in snowfall in Minnesota during winter and wetter conditions overall as reported by Seeley (2006). Consequently, more water exists in the Earth/Atmospheric (E/A) system over Minnesota.

Water, either in its vaporous state or in the form of clouds, will inhibit nocturnal radiation loss. To what extent is this increase in precipitation attributable to natural or anthropogenic causes? The $\mathrm{CO}_{2}$ facet of the problem is all the more complicated because a warmer atmosphere based on anthropogenic $\mathrm{CO}_{2}$ emissions yields an atmosphere with greater potential humidity and assumedly more absolute humidity resulting in a positive feedback (US EPA 2014). However, this situation begs two questions: First, would enhanced absolute humidity actually occur? Second, if it did, would the evaporative cooling and/or resultant cloud cover offset the greenhouse nature of water vapor and thereby eliminate or reduce a potential positive feedback? Again, it is beyond the scope of this work to ascribe specific weights to the factors answering these questions.

However, certain anthropogenic practices related to regional land use at the minimum serve to reinforce our precipitation and temperature findings and their underpinning theme of more water in the E/A system over Minnesota. These plausible anthropogenic agents are discussed in the context of subjects warranting further study to ascertain their significance and specific weight in explaining climate change.

Since the middle 1980s, farmers in the US Midwest (Minnesota included) have been planting over 25,000 corn plants per acre, which has intensified to greater than 32,000 plants per acre in the 1990s (Minnesota State University 2009); a substantial increase from the 1950 average of 8,000 plants acre (Hudson 1994). During late May and throughout June corn is transpiring water vapor into the boundary layer, which has an "incremental effect" on temperature measured at $1.2 \mathrm{~m} \mathrm{(4.5')}$ above the surface (Raddatz 2007). Raddatz (2007) also found intensified agriculture decreased Tmax, a situation that again fits our results. Similarly, Pielke et al. (2007) found that agricultural intensification can comprise a regional cause for extreme precipitation events. Moreover, as maritime tropical (mT) air masses advect through the region during the late spring, summer and early fall, they often gain water vapor (absolute humidity), itself a potent greenhouse gas, thereby limits nocturnal cooling (Changnon et al. 2006). Our temperature results, specifically enhanced Tmin, mirrors this situation.

In addition, since 1965 southern Minnesota and Red River Valley agriculture have experienced an intensification of fall plowing to expose black soils in the spring to foster the decay of the previous year's crop residue and increase soil's temperature (Minnesota Farmer 2013). These wet black soils with their higher specific heat and low albedo absorb more incident solar radiation and then release heat at night. This land use practice again "fits" the warmer 1980-2010 Tmin scenario. As for Grand Rapids, the 1920-1950 period followed an era of near complete clear-cutting of tall pines, whereas today, Grand Rapids lies in the midst of 4 million acres of mature aspen forests (Algren 1984 and USFS 2003). While this landuse/cover change probably does not fully explain the Tmin and precipitation findings at Grand Rapids, it does not counter it and keeps with our main discussion point of regional landuse/cover practices at the minimum reinforcing the statistical findings. 
The longer length of growing season and the earlier start of the growing season during the latter part of the timeframe follow the qualitative findings and predictions of Miller et al. (2005) pursuant to the Corn Belt states of Iowa, Illinois, Indiana and Ohio. Our findings again square with less nocturnal cooling (freezing) driven in part by enhanced $\mathrm{CO}_{2}$ at the global scale and regionally by more precipitation that translates into more water in the E/A system over Minnesota, either in a vaporous state within the boundary layer or as cloud cover aloft. The later end of season finding at Grand Rapids was unique. We have no other regional landcover explanation for Grand Rapids other than the transpiration of moisture from the forest and the canopy's ability to minimize long wave radiation loss in late summer and early fall, whereas at the other three agricultural stations, the crops are either dormant or have been harvested.

\subsection{Direct Short and Long Term Economic Impacts}

The direct short and long-term economic impacts of enhanced precipitation associated with more robust storm activity relate to floodwater storage and conveyance. For example, in southern Minnesota where much of the agricultural landscape contains subterranean artificial drainage to prevent ponding in the corn and soybean fields, the discharge into the region's stream network becomes accentuated resulting in more intense flooding. For example, in 2014, heavy and sustained spring rains combined with an ample winter snowpack produced the wettest half-year (Jan-June) on record since 1871 and resulted over $\$ 50$ million of road damage (Douglas 2014). Subsequent repairs include: (a) raising 4 miles $(6.5 \mathrm{~km})$ of US Highway 169 by five feet $(1.5 \mathrm{~m})$ to meet a revised 100-year flood elevation as its alignment fronts the Minnesota River and, (b) retrofitting a major bridge associated with State Highway 22 crossing the Minnesota River (Minnesota Department of Transportation, 2014).

Finally, the accentuated variability of precipitation within the context of more water in the overall E/A system and the warmer nocturnal minima needs to be evaluated relative to sustaining a corn/soybean based agricultural economy in southern Minnesota and a sugar beet based economic base in the Red River Valley. A similar analysis for sustaining or even intensifying the agro-forestry industry in northeastern Minnesota where aspen serves a major feedstock for paper and oriented strand board (a plywood substitute used in building construction).

\section{Conclusions and Future Research}

To conclude, we found a warmer 1980-2010 based on a significant increase in Tmin at all four stations in Minnesota. We also found the 1980-2010 period to be the most significantly wet of the 91 years. The Change Point analyses results further support these findings. Enhanced $\mathrm{CO}_{2}$ at the planetary scale and a regional increase of water vapor comprise part of the explanation for our findings of increasing Tmin from 1980-2010 at all four Minnesota stations. The combined temperature results from the four stations (Tmin and Tmax) and precipitation trends especially reflect more water in the Earth/Atmosphere system over Minnesota. Other anthropogenic land cover/use practices supplement our findings. Overall, assigning an accurate weight to each factor remains an unsolved problem.

The roles climate change relative to the air mass source regions and jet stream dynamics that foster the transit and residency of very different air masses into Minnesota warrants additional investigation because such research may further explain: (1) the 1980-2010 trends in temperature, precipitation and growing season variables, (2) their future probability of continuance, and (3) allow for a more accurate weighting of causalities, if not quantitatively at least qualitatively.

The net impact of these climate variables on the yields of the main crops, namely corn and soybeans in southern Minnesota and sugar beets in the Red River Valley needs to be addressed. For example, corn yields in 1978 averaged 99 bushels per acre, whereas in 2007, 151 bushels per acre became the norm. The sugar beet yield of 18 tons per acre in 1978 likewise increased to 23.5 tons per acre in 2007 (USDA 1978 and 2007). Hybrid breeding, genetically modified seeds, precision farming practices and better chemicals comprise the main factors behind the yield increase. However, an increase in the growing season, and nocturnal Tmin, along with the increase of precipitation into a non-irrigated regional agricultural regime and a rise in planetary $\mathrm{CO}_{2}$ serve to augment the yield increases. On the other hand, the potential for more extreme weather, e.g. intense precipitation events, hail damage and droughts associated with a warmer atmosphere with a more variable precipitation regime increase the risks of crop damage. Clearly, these potential impacts (positive and negative) warrant further research. Finally, due to the limitations regarding daily climate data processing, only four weather stations located in northwest, northeast, west central and southeast Minnesota were selected and analyzed in this study. In the future, all 69 stations across the state that have long-term data can be processed to interpolate and visualize the spatial patterns of climate changes. 


\section{References}

Algren. C., \& Isabel. (1984). Lob Trees of Minnesota (Minneapolis: University of Minnesota Press) 95.

Bachelet, D., Neilson, R., Lenihan, J. M., \& Drapek, R. J. (2001). Climate Change Effects on Vegetation Distribution and Carbon Budget in the United States. Ecosystems, 4(3), 164-185. http://dx.doi.org/10.1007/s10021-001-0002-7

Baker, D. G., Ruschy, D. L., \& Skaggs, R. H. (1993). Agriculture and the Recent Benign Climate in Minnesota. Bulletin of the American Meteorological Society, 74(6), 1035-1040. http://dx.doi.org/10.1175/1520-0477(1993)074<1035:AATRCI >2.0.CO;2

Brown, C. J., Fulton, E. A., Hobday, A. J., Matear, R. J., Possingham, H. P., Bulman, C., ... Richardson, A. J. (2010). Effects of climate-driven primary production change on marine food webs: Implications for fisheries and conservation. Global Change Biology, 16(4), 1194-1212. http://dx.doi.org/10.1111/j.1365-2486.2009.02046.x

Changnon, D., Sandstrom, M., \& Bentley, M. (2006). Midwestern High Dew Point Events 1960-2000. Physical Geography, 27(6), 494-504. http://dx.doi.org/10.2747/0272-3646.27.6.494

Cleland, E. E., Chuine, I., Menzel, A., Mooney, H. A., \& Schwartz, M. D. (2007). Shifting plant phenology in response to global change. Trends in Ecology \& Evolution, 22, 357-365. http://dx.doi.org/10.1016/j.tree.2007.04.003

Douglas, Paul. (2014). "On Weather," Minneapolis StarTribune. Retrieved June 20, 2014, from http://www.startribune.com/blogs/263922251.html

Durre, I, Gleason, B. E., Houston, T. G., \& Vose, R. S. (2010). Robust automated quality control of daily surface observations. J. Appl. Meteor. Climatol., 49, 1615-1633. http://dx.doi.org/10.1175/2010JAMC2375.1

Grove, Jean. (1990). The Little Ice Age (London: Routledge).

Hart, J. F., \& Ziegler, S. (2008). The Landscapes of Minnesota (St Paul: Minnesota Historical Society) 5-21.

Held, I. M. \& Soden, B. J. (2000). Water vapor feedback and global warming, Annual Rev. Energy Environ, 25, 441-475. http://dx.doi.org/10.1146/annurev.energy.25.1.441

Hudson, J. (1994). Making the Corn Belt (Bloomington, IN: Indiana University Press) 198.

Huntington, T. G. (2006). Evidence for intensification of the global water cycle: Review and synthesis. Journal of Hydrology, 319(1-4), 83-95. http://dx.doi.org/10.1016/j.jhydrol.2005.07.003

Killick, R \& Eckley, I. (2013). Changepoint: An R Package for Changepoint Analysis. Retrieved April 10, 2014, from http://www.lancs.ac.uk/ killick/Pub/KillickEckley2011.pdf

Menne, M. J., Durre, I., Vose, R. S., Gleason, B. E., \& Houston, T. G. (2012). An overview of the global historical climatology network-daily database. Journal of Atmospheric and Oceanic Technology, 29, 897-910. http://dx.doi.org/10.1175/JTECH-D-11-00103.1

Miller, P., Mitchell, M., \& Lopez, J. (2005). Climate Change: Length of Growing Season in the US Corn Belt, 1911-2000. Physical Geography, 26(2), 85-96. http://dx.doi.org/10.2747/0272-3646.26.2.85

Minnesota Department of Natural Resources (MnDNR). (1990). Annual Precipitation Less Evapotranspiration. Retrieved April 21, 2013, from http://www.dnr.state.mn.us/climate/water_availability.html

Minnesota Department of Natural Resources (MnDNR). (2008). Climate Change: Preliminary Assessment for the Wildlife of the Minnesota Department of Natural Resources, (St Paul: Division of Fish and Wildlife) 5.

Minnesota Department of Natural Resources (MnDNR). (2014). Wet June-2014. Retrieved June 25, 2014, from http://www.dnr.state.mn.us/climate/journal/140619_wet_june.html

Minnesota Department of Transportation (MnDOT). (2014). Hwy 169, Hwy 22 Minnesota River Flood Mitigation. Retrieved August 15, 2014, from http://www.dot.state.mn.us/d7/projects/ floodmitigation/index.html

Minnesota Farmer. (2013). 30 Days: Fall Tillage after the Harvest. Retrieved May 15, 2014, from $\mathrm{http}: / /$ minnesotafarm.wordpress.com/tag/deep-tillage-disk/

Minnesota State University. Water Resources Center. (2009). Minnesota River Basin Trends (Mankato MN: Minnesota State University) 10-14.

National Climatic Data Center (NCDC). (2006). Climate of Minnesota. Retrieved from 
http://www5.ncdc.noaa.gov/climatenormals/clim60/states/Clim_MN_01.pdf

National Climatic Data Center (NCDC). (2013). 1981-2010 Normals Data Access. Retrieved from http://www.ncdc.noaa.gov/land-based-station-data/climate-normals/1981-2010-normals-data

National Oceanic and Atmospheric Administration (NOAA). (2014). Drought-Annual 2012. Retrieved June 24, 2014, from http://www.ncdc.noaa.gov/sotc/drought/2012/13\#gp-midwest-sect

Nemani, R., Keeling, C. D., Hashimoto, H., Jolly, W. M., Piper, S. C., Tucker, C. J., Myneni, R. B., \& Running, S. W. (2003). Climate-Driven Increases in Global Terrestrial Net Primary Production from 1982 to 1999. Science, 300(5625). 1560-1563. http://dx.doi.org/10.1126/science.1082750

Pielke, R., Adegoke, J., Beltrand-Przekurat, A., Hiemstra, C., Lin, J., Nair, US., Niyogi, D., \& Nobis, T. (2007). An Overview of Regional Land Use and Land Cover Impacts on Rainfall. Tellus Series B, 59, 587-601. DOI: $10.1111 / j .1600-0889.2007 .00251 . x$

Pielke, R., Walko, R., \& Steyart, L. (1999). The Influence of Anthropogenic Changes on Weather in South Florida. Monthly Weather 1663-1673. http://dx.doi.org/10.1175/1520-0493(1999)127<1663:TIOALC >2.0.CO;2

Raddatz. R. L. (2007). Evidence for the Influence of Agriculture on Weather and Climate through the Transformation and Management of Vegetation: Illustrated by Examples from the Canadian Prairies. Agricultural and Forest Meteorology, 142, 186-202. http://dx.doi.org/10.1111/j.1600-0889.2007.00251.x

Rohli, R., \& Vega, A. (2012). Climatology (Sudbury MA: Jones and Bartlett) 287.

Roy, S. S., \& Yuan, F. (2009). Trends in extreme temperatures in relation to urbanization in Twin Cities Metropolitan Area, Minnesota. Journal of Applied Meteorology and Climatology, 48(3), 669-679. http://dx.doi.org/10.1175/2008JAMC1983.1

Ruschy, D. L., Baker, D. G., \& Skaggs, R. H. (1991). Seasonal variation in daily temperature ranges. Journal of Climate, 4, 1211-1216. http://dx.doi.org/10.1175/1520-0442(1991)004<1211:SVIDTR>2.0.CO;2

Seeley, M. (2006). Minnesota's Weather Almanac (St. Paul: Minnesota Historical Society) 84, 124-127, 260-264.

Skaggs, R. H., \& Baker, D. G. (1985). Fluctuations in the length of the growing season in Minnesota. Climate Change, 7(4), 403-414. http://dx.doi.org/10.1007/BF00139055

Skaggs, R. H., Baker, D. G., \& Ruschy, D. L. (1995). Interannual variability characteristics of the eastern Minnesota (USA) temperature record: implications for climate change studies. Climate Research, 5, 223-227. http://dx.doi.org/10.3354/cr005223

U. S. Department of Agriculture. National Agricultural Statistics Service. (1999). Grain, hay potato, cotton soybean and tobacco production by state. In R. Famighetti (Ed.), WorldAlamanc: Book of Facts (Mahwah, NJ: Primedia Refernce).

U. S. Forest Service. (2003). Minnesota's Forests, 1999-2003 Part A (St. Paul, MN: Northern Research Station) 18. Retrieved May 7, 2013, from http://www.nrs.fs.fed.us/pubs/rb/rb_nrs12.pdf

U.S. Department of Agriculture. (2007). Agricultural Census Table 26 and Table 42.

U.S. Department of Agriculture. (1930). Agricultural Census, Table 119.

U.S. Department of Agriculture. (1978). Agricultural Census, Tables 28 and 10.

U.S. Environmental Protection Agency. (2014). Atmospheric Concentrations of Greenhouse Gases. Retrieved June 26, 2014, from http://www.epa.gov/climatechange/pdfs/print_ghg-concentrations-2014.pdf

World Meteorological Organization. (1982). International Meteorological Vocabulary (2nd ed). (Geneva, Switzerland).

\section{Copyrights}

Copyright for this article is retained by the author(s), with first publication rights granted to the journal.

This is an open-access article distributed under the terms and conditions of the Creative Commons Attribution license (http://creativecommons.org/licenses/by/3.0/). 